This item was submitted to Loughborough's Research Repository by the author.

Items in Figshare are protected by copyright, with all rights reserved, unless otherwise indicated.

\title{
Promoting passenger comfort and wellbeing in the air: an examination of the in-flight health advice provided by international airlines
}

PLEASE CITE THE PUBLISHED VERSION

http://www.sciencedirect.com/science/article/pii/S0969699711000342

\section{PUBLISHER}

(C) Elsevier

VERSION

AM (Accepted Manuscript)

\section{LICENCE}

CC BY-NC-ND 4.0

\section{REPOSITORY RECORD}

Budd, Lucy C.S., Adam P. Warren, and Morag Bell. 2019. "Promoting Passenger Comfort and Wellbeing in the Air: An Examination of the In-flight Health Advice Provided by International Airlines". figshare.

https://hdl.handle.net/2134/8156. 
This item was submitted to Loughborough's Institutional Repository (https://dspace.lboro.ac.uk/) by the author and is made available under the following Creative Commons Licence conditions.

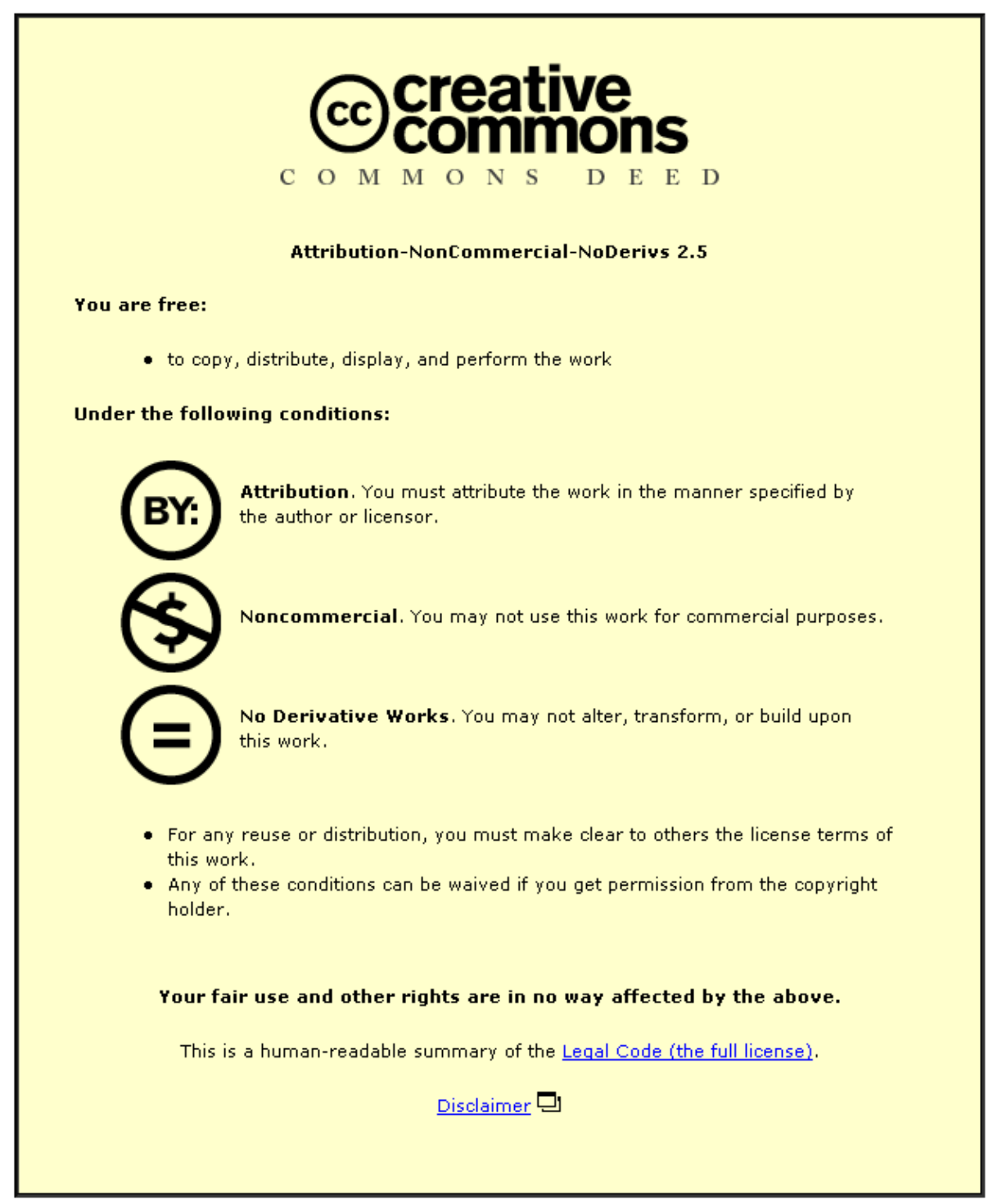

For the full text of this licence, please go to: http://creativecommons.org/licenses/by-nc-nd/2.5/ 
Promoting passenger comfort and wellbeing in the air: an examination of the in-flight health advice provided by international airlines.

Lucy Budd*, Adam Warren** and Morag Bell**

* Transport Studies Group

Department of Civil and Building Engineering

Loughborough University

Loughborough

Leicestershire

LE11 3TU

UK

E-mail: L.C.S.Budd@lboro.ac.uk (Corresponding author)

** Department of Geography

Loughborough University

Loughborough

Leicestershire

LE11 3TU

UK

E-mail: M.Bell@lboro.ac.uk; A.P.Warren@lboro.ac.uk

Keywords: passenger health advice, in-flight magazines, international airlines.

\section{Abstract}

Following recent, well-publicised, cases of airline passengers developing deep vein thromboses (DVT) and contracting infectious diseases during flights, airlines' provision of in-flight customer health advice has come under increased scrutiny. By means of a manifest content analysis of the information that is provided in 50 international airlines' in-flight magazines, this paper examines the nature and presentation of the health advice that is supplied and comments on the different approaches individual airlines adopt.

1. Introduction

As recent reports of airline passengers developing deep vein thromboses (DVT) and contracting infectious diseases during flights has shown, flying can adversely affect the health and wellbeing of passengers. Aside from well-founded concerns surrounding aviation's role in the global transmission of infectious disease, medical research has identified a number of physical and psychological conditions, including jetlag, DVT, airsickness, aerophobia, dehydration, earache and sinus pain, thermal and ocular discomfort, and a range of cardio-respiratory complaints that result from (or are exacerbated by) flying (Backman and Haglighat, 2000; Brown et al., 2001; Dawood, 2003; Foreman, 2003; Waterhouse et al, 2003; Silverman and Gendreau, 2009).

While many of the physical challenges flying poses to the human body have been recognised since the mid-1940s, rising numbers of airline passengers combined with a growing elderly and overweight population mean the medical problems associated with immobility, dehydration, and lower atmospheric pressure, are becoming of increased concern to airlines. In addition to causing distress to passengers and crew, in-flight medical emergencies may necessitate costly and time consuming diversions. 
Many airlines have installed defibrillators and enhanced air filtration systems in their aircraft, contracted third-party medical providers to supply, via direct radio link, inflight diagnostic and medical advice to pilots and cabin crew, and have variously promoted certain mitigation measures, including seat-based exercises and the use of compression stockings. In 2000, a report by the UK House of Lords Select Committee recommended that airlines provide passengers with a pre-flight health briefing that is comparable to the safety briefing as well as carry a standardised health information card in the seat pockets of their aircraft (House of Lords, 2000). Such provision, the report suggests, would help address the present situation in which individual airlines are free to offer as much or as little health advice as they wish.

In order to determine the nature and presentation of the existing health advice airlines provide for their passengers, this paper performs a manifest content analysis of single issues of the in-flight magazines of 50 different international airlines. Unlike competing electronic forms of in-flight 'infotainment', printed in-flight magazines are produced by virtually every major airline around the world and are accessible to passengers at all times during a flight, either from the seat-pocket in front of them or via the cabin crew. However, despite the ubiquity of these publications and their familiarity to all those who fly, academic studies of in-flight magazines remain rare. Where they have occurred, research has tended to focus on the semiotic branding strategies these magazines employ (see, for example, Thurlow and Jaworski, 2003 and Small et al, 2008) and we are not aware of any research that has examined the 'infotainment' sections of these publications or the manifest content of any health advice they contain. This is an unfortunate omission as in-flight magazines represent an important source of passenger information and their contents reflect issues of contemporary interest and concern.

\section{Methodology}

In order to gain an appreciation of the health advice different airlines offer, single issues of 50 international airlines' in-flight magazines, published between May 2003 and May 2010, were examined (Table 1). The use of in-flight magazines as a source of empirical data inevitably presents challenges of selection and interpretation and, although the sample was global in scope and incorporated a number of different airline business models, the choice of examples was shaped by the availability of surviving material. A manifest content analysis (MCA) of each individual in-flight magazine was then performed to determine the presence, presentation, and content of any health advice. Manifest content analysis allows for 'the objective, systematic, and quantitative description of the manifest content of communication' (Berelson, 1952, 18) and enables the explicit (or surface) content of different types of communication to be evaluated and recorded. A coding frame, containing 29 categories which recorded both the textual content and any illustrative material which accompanied any passenger health advice, was developed as a result of an initial scoping study of 20 randomly selected issues.

Table 1: The airlines and in-flight magazines surveyed for this research

\begin{tabular}{llll}
\hline Airline & Region & Magazine title & Date \\
\hline Air Canada & N America & enroute & September 2007 \\
Air France & Europe & Magazine & December 2007
\end{tabular}




\begin{tabular}{|c|c|c|c|}
\hline Air Mauritius & Africa & Islander & January-March 2010 \\
\hline Air New Zealand & Australasia & Magazine & January 2005 \\
\hline Alitalia & Europe & Ulisse & June 2007 \\
\hline All Nippon Airlines & Asia & Wingspan & May 2007 \\
\hline American Airlines & $\mathrm{N}$ America & American Way & June 15th 2008 \\
\hline Austrian Airlines & Europe & skylines & May-June 2008 \\
\hline Bangkok Airways & Asia & fahThai & January-February 2008 \\
\hline bmi & Europe & Voyager & January 2007 \\
\hline bmibaby & Europe & Yeah Baby! & June-July 2007 \\
\hline British Airways & Europe & High Life & April 2009 \\
\hline Brussels Airlines & Europe & b there! & December 2007 \\
\hline CAAC (China) & Asia & CAAC & Summer 2006 \\
\hline Cathay Pacific & Asia & Discovery & July 2008 \\
\hline Copa Airlines & C America & Panorama & October 2008 \\
\hline CSA Czech Airlines & Europe & Review & January-February 2008 \\
\hline Cubana & C America & Sol Y Sol & February 2006 \\
\hline Cyprus Airways & Europe & Sunset & January-March 2008 \\
\hline easyJet & Europe & EasyJet Inflight & June 2009 \\
\hline Egyptair & Africa & Horus & March-April 2007 \\
\hline Emirates & M East & Open Skies & November2007 \\
\hline Etihad & M East & Etihadinflight & June 2008 \\
\hline Finnair & Europe & Blue Wings & May 2008 \\
\hline FlyBE & Europe & uncovered & Winter 2008 \\
\hline Icelandair & Europe & Atlantica & May-June 2007 \\
\hline Jet2 & Europe & JetAway & April-May 2010 \\
\hline Kenya Airways & Africa & msafiri & February-April 2005 \\
\hline KLM & Europe & Holland Herald & September 2007 \\
\hline Korean Air & Asia & Morning Calm & October 2006 \\
\hline Lufthansa & Europe & Magazin & December 2008 \\
\hline Malaysia Airlines & Asia & Going Places & May 2004 \\
\hline Malev & Europe & Horizon & October 2006 \\
\hline Norwegian & Europe & Norwegian.no & Summer 2007 \\
\hline Qantas & Australasia & The Australian Way & June 2008 \\
\hline Qatar Airways & M East & Oryx & May 2008 \\
\hline Royal Brunei & Asia & Muhibah & May-June 2004 \\
\hline Ryanair & Europe & Ryanair Magazine & September-October 2008 \\
\hline SAS & Europe & Scanorama & October 2007 \\
\hline Silk Air (Singapore) & Asia & Silkwinds & December 2007 \\
\hline Singapore Airlines & Asia & Silverkriss & November 2007 \\
\hline Sterling & Europe & Sterling & May-June 2008 \\
\hline Swiss & Europe & Magazine & Winter 2008 \\
\hline TAP Air Portugal & Europe & Atlantis & March-April 2007 \\
\hline Thai & Asia & Sawasdee & February 2008 \\
\hline Thomsonfly & Europe & fly & Summer 2007 \\
\hline Turkish Airlines & Europe & Skylife & May 2007 \\
\hline United Airlines & $\mathrm{N}$ America & Hemispheres & May 2003 \\
\hline Welcome Air & Europe & Welcome in the air & Winter 2006/07 \\
\hline XL Airways & Europe & Altitude & Winter 2006/07 \\
\hline
\end{tabular}


Of the 50 in-flight magazines that were examined, 36 belonged to 'legacy' or full service carriers, eight to low-cost operators, four (including Welcome Air of Austria) to regional airlines, and two (XL and Thomsonfly) to hybrid charter/low-cost operators. In terms of geographic origin, 27 of the airlines originated in Europe, 10 in Asia/Far East, and the remainder from Africa (3), the Middle East (3), North America (3), Australasia (2), and Central/South America (2). Of the 50 magazines, 27 were published in English only, 17 were bilingual (in each case English plus the native language), and five were multi-lingual and published in at least three world languages.

\section{Principal findings}

Of the 50 magazines surveyed, 17 titles (34\%) did not contain any form of in-flight passenger health advice. Of the 33 that did, the physical location, space, content, and presentation of the advice varied considerably. The majority (31 out of 33) positioned the health advice at or near the back of the magazine alongside other passenger information such as details about the in-flight entertainment system, aircraft fleet, route maps, airport diagrams, and customs and immigration requirements. Only two carriers, Cyprus Airways and Kenya Airways, positioned the passenger health information at or near the front of their magazines. While the majority of airlines (18/33) devoted an entire page of their in-flight magazine to passenger health advice, four carriers devoted two full pages, while that of seven operators occupied less than half a page.

In addition to determining the presence, location, and size of any health advice, the MCA also sought to uncover the nature of the health risks different airlines had identified as being potentially problematic. In every case, these 'risks' were associated with six particular characteristics of the airborne environment. The dangers posed by immobility and/or poor circulation (conditions which promote the formation of DVT) were the most common category and were explicitly cited in 18 magazines. Health risks associated with dehydration and jetlag were mentioned in 13 and 12 titles respectively, while discomfort resulting from cabin pressurisation, low humidity, airsickness, and cabin air quality were highlighted by relatively few titles (Table 2).

Table 2: Frequency with which particular 'risks' were mentioned

\begin{tabular}{lc}
\hline Risk & Frequency \\
\hline Poor circulation/immobility (DVT) & 18 \\
Dehydration & 13 \\
Jetlag & 12 \\
Pressurisation & 5 \\
Low Humidity & 4 \\
Cabin Air Quality & 1 \\
\hline
\end{tabular}

Of the 33 magazines that contained some form of health advice, only 25 explicitly mentioned one or more of these risk factors. The remaining eight made no reference to specific health risks but offered generalised advice on the desirability of 'taking care' in the air. Of the 25 magazines that did mention specific risks, 13 discussed only one while the in-flight magazines of two long-haul carriers, Qantas and Cathay Pacific, mentioned all six. It could be argued that these differences reflect an 
individual airline's route network, with carriers who regularly perform long-haul sectors and cross multiple time-zones in the course of a single flight more likely to mention multiple risks than carriers which only perform short-haul services.

Interestingly (and irrespective of whether DVT was explicitly mentioned in the text), 32 of the 33 magazines that contained some form of passenger health advice described, in greater or lesser detail, a series of seated 'airobics' exercises that passengers could perform to increase circulation and lessen the discomfort associated with long periods of immobility. 27 of these were accompanied by illustrations which usually took the form of Computer Generated Images (CGI) of adult (predominately, although not exclusively, female and white) passengers performing shoulder rolls, ankle rotations, and other seated exercises. Several airlines were keen to reassure their passengers that their exercise regimes had been devised or endorsed by a registered medical practitioner and thus were safe, appropriate, and medically beneficial. Two airlines had even obtained 'sponsorship' for their in-flight exercise programme from health spas and 'wellness' centres.

In addition to identifying specific 'risk' factors, many airlines also offered more general advice about wellbeing in the air and made suggestions as to how individual passengers could lessen the physical effects of flying (Table 3). 22 carriers recommended that passengers should keep themselves hydrated with water or fruit juice to combat the relatively low cabin air humidity and 19 suggested that their customers might derive benefit from avoiding caffeinated or alcoholic drinks.

Table 3: Specific advice regarding passenger wellbeing in the air

\begin{tabular}{lc}
\hline Advice & Frequency \\
\hline Keep hydrated & 22 \\
Avoid caffeinated/alcoholic drinks & 19 \\
Walk around the cabin & 14 \\
Eat small quantities of food & 11 \\
Wear comfortable clothing & 8 \\
Moisturise skin/lips & 8 \\
Remove contact lenses & 8 \\
Suck sweets (to reduce ear pain) & 5 \\
Wear compression stockings & 4 \\
Avoid tight clothing & 3 \\
\hline
\end{tabular}

14 airlines recommended that passengers should move around the cabin during the flight to avoid cramp and possible DVT and four of these operators advocated the use of compression stockings to promote venous circulation. 11 airlines advised their customers to only eat small quantities of food onboard, while four specifically suggested minimising salt and/or sugar intake. Eight of the 25 carriers who provided some form of passenger health advice suggested that passengers should wear comfortable clothing, regularly moisturise skin and lips and exchange contact lenses for conventional glasses, the latter to reduce the drying effects of low cabin air humidity and ocular discomfort. 
While much of the health advice was largely generic, some carriers did offer very specific recommendations. Air Canada and Ethiad, for example, respectively advised their customers to avoid eating fatty foods or dairy products, while Finnair suggested that passengers should consume a minimum of two deci-litres of non-alcoholic drinks every hour. Others airlines advised that, for certain categories of 'at risk' traveller, including the elderly and those with poor circulation, the self-administration of some form of pre-flight or in-flight medication might be appropriate. Despite only operating short-haul intra-European services, Sterling, a former Danish low-cost airline, suggested that passengers take 100-125mg of aspirin on the day of travel to reduce the risk of thromboses while Qatar Airways suggested that passengers prone to sinus pain might obtain relief from over-the-counter decongestants. While it could be argued that such variations reflect the prominence each airline gives to the issue of passenger health, this claim must not be overstated. Indeed, the editorial position of the (often third party) publishing companies who edit and produce the magazines and commercial pressure to maximise advertising revenue and minimise the space given to non-revenue generating features are also likely to influence the provision of health advice.

\section{Discussion and conclusion}

While we appreciate that in-flight magazines are not the only source of health advice available to airline passengers, and that many carriers provide information in alternative formats on their websites and via their in-fight entertainment systems, magazines nevertheless remain one of the primary sources of flight-related information. The manifest content analysis of the health advice contained within single issues of a sample of 50 international airlines' in-flight magazines revealed considerable variation in the content and presentation of health advice. Nearly one third of the in-flight magazines that were surveyed contained no health advice whatsoever, while the advice in those that did varied from short and generic descriptions of steps that could be taken to help preserve in-flight 'wellness' to detailed information on behavioural and nutritional strategies that could be adopted in an attempt to safeguard personal health and wellbeing. Interestingly, we found no clear relationship between an airline's route network, brand proposition, or nationality and the nature of the in-flight health advice that was (or was not) provided.

\section{References}

Backman, H. and Haglighat, F. 2000. Air quality and ocular discomfort aboard commercial aircraft. Optometry. 71(10), 653-656.

Berelson, B. 1952. Content analysis in communication research. Glencoe, IL, Free Press.

Brown, T. P., Shuker, L. K., Rushton, L., Warren, F., and Stevens, J. 2001. The possible effects on health, comfort, and safety of aircraft cabin environments. The Journal of the Royal Society for the Promotion of Health. 121(3), 177-184.

Dawood, R. 2003. Physiology of flying: Effects and consequences of the cabin environment in Bor, R. (Ed.) Passenger Behaviour Ashgate, Aldershot pp. 223231.

Foreman, E. I. 2003. Just Plane Scared? An Overview of fear of flying in Bor, R. (Ed.) Passenger Behaviour Ashgate, Aldershot pp.50-59. 
House of Lords. 2000. Select Committee on Science and Technology. Fifth Report. Air Travel and Health. Available online at http://www.parliament.the-stationeryoffice.co.uk/pa/ld199900/ldselect/ldsctech/121/12101.htm.

Silverman, D. and Gendreau, M. 2009. Medical issues associated with commercial flights. The Lancet. June 13 373(9680), 2067-2077.

Small, J., Harris, C., and Wilson, E. 2008. A Critical Discourse Analysis of In-flight Magazine Advertisements: The 'Social Sorting' of Airline Travellers? Journal of Tourism and Cultural Change 6(1), 17-38.

Thurlow, C. and Jaworski, A. 2003. Communicating a global reach: Inflight magazines as a globalizing genre in tourism Journal of Sociolinguistics 7(4), 579606

Waterhouse, J., Reilly, T., and Edwards, B. 2003. Long haul flights, Travel fatigue, and Jet Lag in Bor, R. (Ed.) Passenger Behaviour Ashgate, Aldershot pp.246-260.

Acknowledgements

We would like to thank the two anonymous reviewers for their helpful comments on an earlier version of this paper. 